\title{
KARAKTERISTIK IKAN NILA (Oreochromis niloticus) DAN IKAN LELE (Clarias sp.)PADA FASE RIGOR MORTIS
}

\author{
AB. Chandra ${ }^{a}{ }^{*}$, Abdus S. J ${ }^{a}$, Nur Dina K. ${ }^{b}$, Masrifatul A. ${ }^{\text {, }}$, M. Zainuri ${ }^{a}$

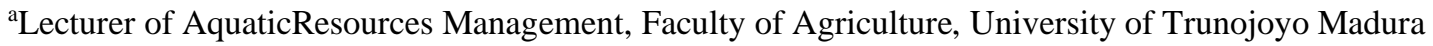 \\ Raya Telang St. PO BOX 2, Bangkalan, Indonesia \\ ${ }^{\mathrm{b}}$ StudentofAquatic Resources Management, Faculty of Agriculture, University of Trunojoyo Madura \\ Raya Telang St. PO BOX 2, Bangkalan, Indonesia
}

*Koresponden penulis : a.bobbychandra@trunojoyo.ac.id

\begin{abstract}
Abstrak
Tujuan penelitian ini adalah untuk mengkarakterisasi ikan nila dan ikan lele pada fase rigor mortis. Penelitian ini menggunakan metode deskriptif dengan parameter organoleptik dan derajat keasaman. Hasil penelitian menunjukkan bahwapH ikan nila dan ikan lele 1,5jam setelah matiberturut-turut adalah 6.96 dan 6.67. Rata-rata nilai pH ikan nila dan ikan lele menurun 2jam setelah mati, yaitu 6.66 dan 6.45. Selanjutnya nilai rata-rata $\mathrm{pH}$ ikan nila dan ikan lele menurun drastis hingga pengamatan pada jam ke 14, yaitu 6.15 dan 6.06. Ikan nila dan ikan lele memasuki fase rigormortis $2 \mathrm{jam}$ setelah mati dan mulai memasuki fase post-rigormortis pada $12 \mathrm{jam}$ setelah mati. Hasil uji secara organoleptik ikan nila dan ikan lele selama 14 jam pengamatan menunjukkan tingkat kesegaran yang menurun dengan ciri-ciribola mata agak cekung, warna insang merah kecoklatan, lendir dipermukaan badan menggumpal, tekstur daging kurang elastis, dan mulai tercium bau amoniak.
\end{abstract}

Kata kunci: Organoleptik, pH, Oreochromis niloticus, Clarias sp., rigor mortis

\begin{abstract}
The purpose of this research was to characterize tilapia and catfish in the rigor mortis phase. This research used a descriptive method with organoleptic parameters and the degree of acidity $(\mathrm{pH})$. The result showed that the $\mathrm{pH}$ of tilapia and catfish 1.5 hours after death were 6.96 and 6.67, respectively. The average $\mathrm{pH}$ value of tilapia and catfish decreased 2 hours after death, namely 6.66 and 6.45. Furthermore, the average $\mathrm{pH}$ value of tilapia and catfish decreased dramatically until the observation at the $14^{\text {th }}$ hour, namely 6.15 and 6.06. Tilapia and catfish enter the rigor mortis phase 2 hours after death and begin to enter the post-rigor mortis phase at 12 hours after death. The organoleptic test results of tilapia and catfish for 14 hours of observation showed a decreased level of freshness, with the characteristics of slightly sunken eyes, brownish red gills, lumpy mucus on the surface of the body, lesselastic meat texture, and a smell of ammonia.
\end{abstract}

Keywords: Organoleptic, pH, Oreochromis niloticus, Clarias sp., rigor mortis

\section{Pendahuluan}

Mutu dan kualitas ikan dapat ditentukan dari berbagai hal, diantaranya adalah karakteristik daging, tekstur, bau, bentuk mata, warna insang, lendir di permukaan kulit, suhu habitat tempat ikan hidup, jenis ikan, cara penangkapan, dan cara penanganan $[1,2,6]$. Setelah ikan ditangkap dari perairan, mutu dan kualitas ikan akan mengalami kemunduran mengikuti beberapa fase, yaitu fase pre-rigor mortis, fase rigor mortis, dan fase post-rigor mortis. Fase pre-rigor mortis dimulai sesaat setelah ikan mati hingga 2-6 jam kedepan yang diikutii dengan perubahan metabolisme dari aerob ke anaerob. Pada fase ini masih terjadi kontraksi aktin dan miosin dengan menggunakan sisa Adenosin trifosfat (ATP) hasil metabolisme aerob $[1,5,6]$. Setelah ATP sebagai sumber energi tinggi telah habis, ikan memasuki fase rigor mortis yang ditandai dengan kejang otot. Kejang pada fase rigor mortis disebabkan oleh aktin dan miosin yang tidak berkontraksi pada otot ikan. Selanjutnya fase post-rigor mortis atau relaksasi yang ditandai dengan kontraksi aktin dan miosin dengan menggunakan energi sisa dari metabolisme anaerob. Setelah relaksasi selesai, daging ikan mengalami proses pembusukan oleh beragam mikroba $[8,9,10]$.

Kemunduran mutu dan kualitas ikan juga dapat ditentukan dengan melihat derajat keasaman $(\mathrm{pH})$. Ikan yang segar ditandai dengan nilai $\mathrm{pH}$ yang mendekati nilai netral $(\mathrm{pH} 7)$. Apabila nilai $\mathrm{pH}$ cenderung asam, maka dapat 
dipastikan kualitas ikan sudah mulai menurun [2, 7].

Memahami beragam karakteristik kemunduran mutu dan kualitas ikan dengan baik dapat menentukan strategi penanganan hasil perikanan dengan tepat.Karakteristik yang dipahami dengan baik misalnya dapat diterapkan dengan memperpanjang fase pre-rigor mortis sehingga kualitas dan mutu ikan dapat dipertahankan. Apabila tidak ada penanganan, maka proses kemunduran mutu ikan akan terus berlangsung. Oleh karena itu, data-data mengenai karakteristik ikan pada fase rigor mortis sangat penting dalam menunjang usaha mempertahankan mutu dan kualitas ikan. Masih terbatasnya pustaka mengenai karakteristik rigor mortis pada ikan air tawar menjadi urgensi dari penelitian ini dilakukan.

\section{BAHAN DAN METODE}

Metode yang digunakan dalam penelitian ini dengan pendekatan deskriptif. Adapun sampel penelitian yang digunakan adalah ikan nila dan ikan lele dengan bobot rata-rata 250-300 gram setiap ekornya, diperoleh dari Pasar Lemah Duwur, Bangkalan dalam keadaan hidup lalu ditampung dalam akuarium dan diberikan aerator.Bahan lain yang digunakan adalah es curai, larutan bufferpH 4, 7, dan 10, sertaakuades Alat-alat yang digunakan dalam penelitian ini adalah pH meter (AZ 8601), timbangan analitik (FS-AR210), pisau bedah (GoldCross), coolbox, mikropipet, termometer infrared(GM 320), dan peralatan gelas lainnya.

Penelitian ini dilakukan dengan mengamati sampelberdasarkan parameter uji organoleptik (SNI-01-2346-2006) yang meliputi bentuk mata, insang, lendir dipermukaan tubuh, bau, dan tekstur daging. Selanjutnya dalam waktu yang bersamaan sejumlah 5 gram daging ikan nila dan ikan lele dicincang dan diberikan bufferpH 7 untuk diamati derajat keasamannya $(\mathrm{pH})$ tiap selang waktu 30 menit selama 14 jam pengamatan.

\section{Hasil dan Pembahasan}

Hasil uji derajat keasaman $(\mathrm{pH})$ ikan nila (O.niloticus) dan ikan lele (Clarias sp.) selama 14 jam disajikan pada Tabel 1. Berdasarkan pengamatan pada fase awal pre-rigormortis selama $1.5 \mathrm{jam}$ setelah mati diperoleh rata-rata $\mathrm{pH}$ ikan nila dan ikan lele adalah 6.96 dan 6.67. Selanjutnya , nilai rata-rata $\mathrm{pH}$ ikan nila dan ikan lele menurun memasuki jam ke-2 sampai dengan jam ke-10 setelah mati saat fase rigor mortis dimulai yaitu 6.66 dan 6.45. Penurunan rata-rata nilai $\mathrm{pH}$ ikan nila dan ikan lele terus berlanjut memasuki jam ke-10 sampai dengan jam ke-14 saat fase post-rigor mortis dimulai, yaitu 6.15 dan 6.06 .

Tabel 1 Hasil uji pH $O$. niloticus dan Clarias $s p$. selama 14 jam

\begin{tabular}{ccc}
\hline \multirow{2}{*}{ Jam Ke- } & \multicolumn{2}{c}{$\mathbf{p H}$} \\
\cline { 2 - 3 } & O. niloticus & Clarias sp. \\
\hline 0.5 & 6.96 & 6.70 \\
1 & 6.96 & 6.70 \\
1.5 & 6.96 & 6.66 \\
2 & 6.91 & 6.66 \\
2.5 & 6.90 & 6.65 \\
3 & 6.88 & 6.64 \\
3.5 & 6.68 & 6.64 \\
4 & 6.77 & 6.60 \\
4.5 & 6.74 & 6.55 \\
5 & 6.74 & 6.52 \\
5.5 & 6.74 & 6.50 \\
6 & 6.73 & 6.50 \\
7 & 6.63 & 6.48 \\
8 & 6.55 & 6.40 \\
9 & 6.43 & 6.31 \\
10 & 6.39 & 6.24 \\
11 & 6.20 & 6.13 \\
12 & 6.18 & 6.09 \\
13 & 6.14 & 6.07 \\
14 & 6.12 & 6.03 \\
\hline
\end{tabular}

Asupan oksigen yang terhenti pada fase awal kematian ikan menyebabkan perubahan metabolisme dari aerob menuju metabolisme anaerob. Metabolisme anaerob yang diaktivasi bertujuan untuk menghidrolisis glikogen sebagai sumber energi tinggi, yaitu adenosin trifosfat (ATP).Hidrolisis glikogen untuk produksi ATP melalui metabolisme anaerob juga menghasilkan asam laktat yang ditandai dengan menurunnya $\mathrm{pH}$. Berdasarkan pengamatan, penurunan nilai $\mathrm{pH}$ dapat dijadikan salah satu indikator sederhana perubahan fase, yaitu dari fase pre-rigor mortis menuju fase rigor mortis.

Suhu ikan nila dan ikan lele hasil pengamatan sesaat setelah mati, yaitu $27.6{ }^{\circ} \mathrm{C}$ dan $26.6{ }^{\circ} \mathrm{C}$. Suhu kedua jenis ikan ini tidak mengalami perubahan yang nyata sampai dengan pengamatan jam ke-14. Berdasarkan pengamatan 
sampai dengan jam ke-14, perubahan $\mathrm{pH}$ pada ikan nila dan ikan lele tidak diikuti dengan perubahan suhu dari kedua jenis ikan ini.

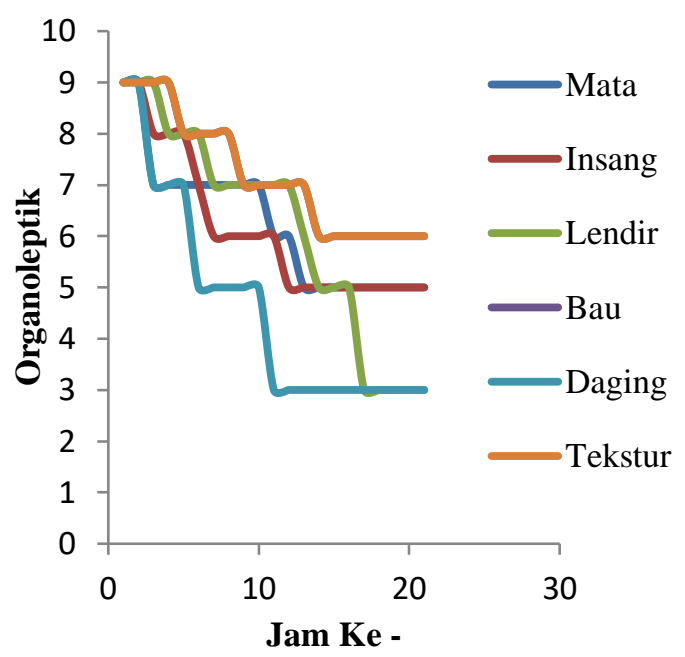

Gambar 1 Hasil uji organoleptik $O$. niloticus

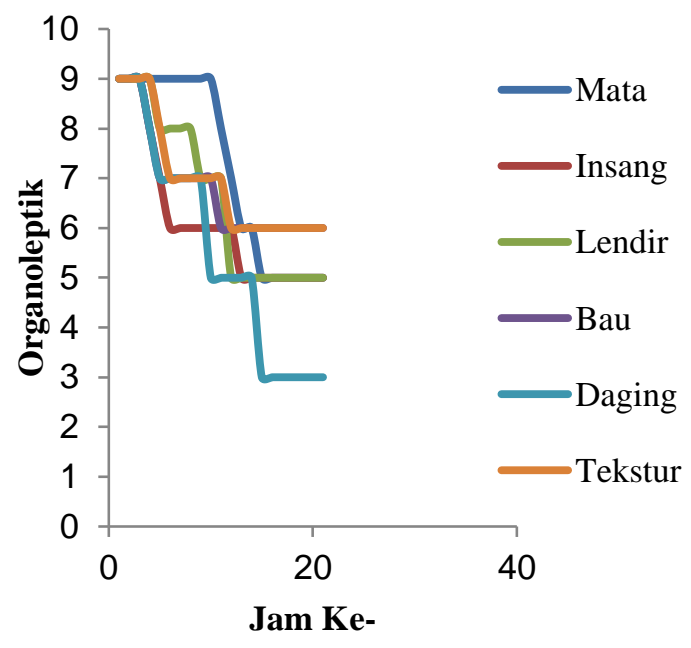

Gambar 2 Hasil uji organoleptik Clarias sp.

Hasil uji organoleptik ikan nila dan ikan lele masing-masing disajikan pada Gambar 1 dan Gambar 2. Data pengamatan pada jam ke-0 ikan nila dan ikan lele sama-sama menunjukkan nilai 9 untuk semua parameter organoleptik.Sesuai pada Gambar 1 dan Gambar 2, karakteristik mata, insang, dan lendir permukaan badan yang diamati terhadap ikan nila dan ikan lele pada jam ke-0 adalah kondisi mata yang cerah, bola mata menonjol, kornea jernih, warna insang merah cemerlang tanpa lendir, dan lapisan lendir di permukaan badan jernih, transparan serta mengkilat cerah.Selanjutnya untuk karakteristik daging, bau, dan tekstur ikan nila dan ikan lele adalah sayatan daging cemerlang, tidak ada pemerahan sepanjang tulang belakang, dinding daging perut utuh, bau sangat segar (spesifik sesuai jenis ikan), tekstur padat elastis, dan sulit menyobek daging dari tulang belakang. Ikan nila dan ikan lele yang baru mati masih mempunyai sisa ATP yang menyebakan otot masih bisa relaksasi. Karakteristik ini terus berlanjut hingga 60menit, yaitu saat ikan nila dan ikan lele masih memasuki fase pre-rigormortis.

Berdasarkan Gambar 1 dan Gambar 2, karakteristik ikan nila dan ikan lele mulai mengalami perubahan memasuki jam ke-2. Perubahan karakteristik yang diamati pada ikan nila dan ikan lele mulai jam ke-2 adalah bentuk bola mata yang rata, warna insang merah kurang cemerlang, dan lapisan lendir di permukan badan cerah tidak mengkilat. Perubahan karakteristik mata, insang, dan lendir pada ikan nila dan ikan lele terus berlanjut hingga pengamatan pada jam ke-14. Sampai dengan jam ke-14 perubahan yang diamati adalah bola mata agak cekung, pupil keabu-abuan, kornea agak keruh, mulai ada perubahan warna insang menjadi merah kecoklatan disertai sedikit lendir, lendir di permukaan badan menggumpal dan berwarna putih kuning.

Karakteristik daging, bau, dan tekstur ikan nila dan ikan lele sampai dengan akhir pengamatan jam ke-14 (Gambar 1 dan Gambar 2) menunjukan sayatan daging kusam, warna merah jelas sekali sepanjang tulang belakang, dinding perut lunak, bau amoniak mulai tercium disertai sedikit bau asam, tekstur lunak, kurang elastis bila ditekan dengan jari, dan agak mudah menyobekdaging dari tulang belakang.Timbulnya sedikit bau asam pada ikan nila dan ikan lele adalah faktor asam laktat yang dihasilkan dari metabolisme anaerob.Munculnya perubahan karakteristik pada ikan nila dan ikan lele dikarenakan sisa ATP yang tidak cukup untuk merombak aktomiosin menjadi aktin dan miosin. Sehinggaototikanmulaimenjadikakudankeras.

Berdasarkan penelitian terdahulu karakteristik ikan nila [4] dan beberapa jenis ikan [1] pada fase rigor mortis diantaranya dipengaruhi oleh jenis ikan, habitat dan tingkat pencemaran daerah tangkapan, cara penanganan pascapanen, suhu, dan cara penyimpanan $[1,3,5$, 6]. Karakteristik bola mata, lender dipermukaan badan, tekstur daging, dan bau beragam jenis ikan terus mengalami kemunduran setelah melewati fase rigor mortis $[1,2]$.

\section{KESIMPULAN}


Hasil penelitian menunjukkanbahwa ratarata pHikan nila dan ikan lele $1.5 \mathrm{jam}$ setelah mati berturut-turut adalah 6.96 dan 6.67. Rata-rata nilai $\mathrm{pH}$ ikan nila dan ikan lele menurun $2 \mathrm{jam}$ setelah mati, yaitu 6.66 dan 6.45. Nilai rata-rata $\mathrm{pH}$ ikan nila dan ikan lele menurun drastis hingga pengamatan pada jam ke-14, yaitu 6.15 dan 6.06. Hasil uji secara organoleptik ikan nila dan ikan lele selama 14 jam pengamatan menunjukkan tigkat kesegaran yang menurun dengan ciriciribola mata agak cekung, warna insang merah kecoklatan, lendir dipermukaan badan menggumpal, tekstur daging kurang elastis, dan mulai tercium bau amoniak.

\section{UCAPAN TERIMA KASIH}

Penulis menyampaikan terima kasih kepada Koorprodi Manajemen Sumberdaya Perairan dan Pranata Laboratorium Pengelolaan Sumberdaya Perikananatas bantuannya sehiggapenelitian ini dapat dilaksanakan dengan baik.

\section{DAFTAR PUSTAKA}

[1] Abdul J. Perbedaan Laju Perkembangan Rigor Mortis Beberapa Jenis Ikan. Jurnal Harpodon Borneo Vol. 8 (2):94-98. 2015.

[2] Badan Standardisasi Nasional (BSN). Petunjuk Uji Organoleptik Ikan Segar Standar Nasional Indonesia. SNI-01-23462006. Jakarta: Standar Nasional Indonesia.

[3] Badan Standardisasi Nasional (BSN). Standar Nasional Indonesia Ikan Segar. SNI-01-2729-1992. Jakarta: Standar Nasional Indonesia.

[5] Eddy S. KajianKesegaranIkan di PasarTradisionaldan Modern Kota Malang. Journal of Fisheries and Marine Research Vol. 4 (2):289-295.2020.
[6] Evi J dan Eddy A. Penentuan Waktu Rigor mortis Ikan Nila Merah (O. niloticus) Berdasarkan Nilai Derajat Keasaman. Jurnal Akuatika Vol. V:1 (4044).Universitas Padjadjaran. 2014

[7] Eskin NAM. Biochemistry of Food. Second Edition. San Diego: Academic Press, Inc. 1990.

[8] Lee KH., Tsuchimoto M., Onishi T., Wu ZH., Jabarsyah A., Mishima T., Tachibana K. Differences in Progress of Rigor Mortis Between Wild and Cultured Japanese Flounder. The Journal of Fisheries Science. Vol. 64 (2):309-313). 1998.

[9] Grigor JM, Theaker JB, Alasalvar C, O'hare WT, Ali Z. Analysis of Seafood Aroma/Odour by Electronic Nose Technology and Direct Analysis. Dalam Seafood-Quality, Technology and Nutraceutical Applications. New York: Springer. 2002.

[10] Yunizal dan Wibowo S. Penanganan Ikan Segar. Jakarta: Pusat Penelitian dan Pengembangan Perikanan. 1998. 